ISSN: 2162-3104 Print/ ISSN: 2166-3750 Online

Volume 10, Issue S3 (2020), pp. i-xii

(C) Journal of International Students

https://ojed.org/jis

Editorial Tamu

[Guest Editorial]

\title{
Introduction to International Students and COVID-19
}

\section{Mahasiswa Internasional dan COVID-19}

\author{
Handoyo Puji Widodo \\ King Abdulaziz University (KAU), Jeddah, Saudi Arabia \\ Sandi Ferdiansyah \\ Institut Agama Islam Negeri (IAIN) Jember, Indonesia
}

\author{
Lara Fridani \\ Universitas Negeri Jakarta, Indonesia
}

\begin{abstract}
In this special edition, we address international students and COVID-19 in the higher education context. To begin with, three articles explore the sources of information used by Indonesian students interested in studying abroad, challenges faced by international students who studied in Indonesia, and the psychological wellbeing of Indonesian students studying in Taiwan. Although empirical studies reported in those three articles were undertaken before the prevalence of the COVID-19 pandemic, they are still relevant to this edition because they address practical implications for post-pandemic overseas studies. Other articles look into different dimensions of international students' academic and non-academic experiences during the COVID-19 pandemic. We hope that this special edition can provide a better understanding of international students in the COVID1-19 pandemic context and beyond.
\end{abstract}


Abstrak: Dalam edisi khusus ini, kami membahas isu mahasiswa internasional dan COVID-19 dalam konteks pendidikan tinggi. Pertama, tiga artikel mengeksplorasi isu mengenai penggunaan sumber informasi studi lanjut ke luar negeri, tantangan mahasiswa internasional yang belajar di Indonesia, serta kesejahteraan psikologis mahasiswa Indonesia yang belajar di Taiwan. Meskipun studi empiris yang dilaporkan dalam ketiga artikel tersebut dilakukan sebelum terjadinya pandemi COVID-19, ketiganya masih terkait dengan edisi ini karena hasil-hasil riset yang dilaporkan dalam ketiga artikel tersebut memberikan implikasi praktis terhadap studi luar negeri di pascapandemi global. Artikel-artikel lainnya mengkaji dimensi lainnya mengenai pengalaman akademik dan non-akademik mahasiswa internasional. Kami berharap bahwa edisi khusus ini dapat memberikan wawasan baru mengenai mahasiswa internasional dalam konteks pandemi COVID-19 dan pascapandemi.

Keywords: COVID-19, international students, higher education, overseas studies [COVID-19, mahasiswa internasional, pendidikan tinggi, studi di luar negeri]

\section{RASIONAL}

Internasionalisasi pendidikan tinggi menyebabkan mobilisasi mahasiswa internasional di berbagai belahan dunia, dan jumlah mahasiswa internasional semakin bertambah. Akan tetapi, sejak terjadinya pandemi COVID-19 secara global, jumlah mahasiswa internasional mengalami penurunan yang cukup signifikan dibandingkan tahun-tahun sebelumnya (The Guardian, 2020). Padahal sebelum masa pandemi, beberapa negara seperti Amerika, Australia, Cina dan Inggris memiliki mahasiswa internasional dalam jumlah yang terus meningkat dalam kurun waktu dua puluh tahun terakhir (UNESCO, 2019). Pandemi COVID-19 telah mengakibatkan perubahan yang besar di berbagai belahan dunia yang berdampak pada segala bidang kehidupan, termasuk dunia pendidikan. Pemerintah di berbagai negara memberlakukan kebijakan pembatasan berskala besar yang secara langsung menyebabkan terhambatnya akses mahasiswa internasional dalam berinteraksi sosial baik di dalam kampus maupun di luar kampus. Kondisi yang tidak bisa dipastikan selama masa pandemi ini memengaruhi kehidupan akademik, sosial dan psikologis mahasiswa internasional (Tran, 2020).

Di masa pandemi ini, mahasiswa internasional mengalami berbagai tantangan dalam melanjutkan studinya. Pembelajaran daring diberlakukan sebagai salah satu upaya yang efektif untuk mengatur jarak fisik dan sosial untuk menghambat penyebaran COVID-19 (Baloran 2020; Bayham \& Fenichel, 2020; Blankenberger \& Williams, 2020; Murphy, 2020). Mahasiswa internasional tidak hanya beradaptasi dengan perubahan dalam sistem pembelajaran (Azorin, 2020), namun mereka juga harus berupaya mengatasi masalah kesehatan fisik dan mental, motivasi, kedisiplinan dan perasaan terisolasi (Raaper \& Brown, 2020). Sehubungan dengan hal ini, tidak sedikit mahasiswa internasional yang berjuang dalam hal kesejahteraan, pengaturan akomodasi, keuangan dan hubungan dengan masyarakat atau komunitas setempat. Tantangan lain yang dihadapi oleh mahasiswa internasional terkait 
dengan masalah keluarga, keterampilan belajar, penyesuaian kehidupan kampus, kegiatan ekstrakurikuler dan target waktu kelulusan studi (Haverila, Haverila \& McLaughlin, 2020; Urban, Orbe, Taveres \& Alvares, 2010). COVID-19 menginterupsi bidang pendidikan tinggi (Cleland, McKimm, Fuller, Taylor, Janczukowicz \& Gibbs, 2020) dan menambah kompleksitas masalah yang dihadapi oleh para mahasiswa internasional baik dalam hal akademik maupun dalam hal nonakademik. Walaupun ada sebagian mahasiswa internasional yang dapat mengambil hikmah dari dampak pandemic ini, secara umum, mereka mengalami tantangan yang lebih berat dibandingkan masa sebelum terjadinya pandemi. Dengan demikian, kami perlu mendokumentasikan pengalaman, tantangan dan upaya yang dilakukan oleh mahasiswa internasional dalam menghadapi situasi yang kurang kondusif di masa pandemi global. Oleh karena itu, edisi khusus ini menyajikan berbagai hasil penelitian mengenai perjuangan yang dilakukan oleh mahasiswa internasional dalam membuat keputusan untuk studi hingga menuntaskan studinya, khususnya di masa pandemi COVID-19.

\section{GEOGRAFI EMOSI, KESEJAHTERAAN PSIKOLOGIS, DAN PENDEKATAN SOSIAL BUDAYA SEBAGAI KERANGKA TEORETIS DAN KONSEPTUAL}

Dalam literatur mahasiswa internasional, beragam pendekatan teoretis dan konseptual digunakan untuk mengkaji berbagai dimensi pengalaman mahasiswa internasional dari aspek akademik, fisik, psikologis (emosi), sosial budaya dan spiritual. Khususnya di masa pandemi COVID-19 ini, perlu adanya sebuah pendekatan yang memberi wawasan baru mengenai pengalaman mahasiswa internasional, seperti geografi emosi/teori emosi kesejahteraan psikologis sosial dan pendekatan sosial budaya. Selain itu, dari sudut pandang linguistik sosial, linguistik fungsional sistemik bisa digunakan sebagai landasan teoretis dan konseptual untuk mengkaji pengalaman mahasiswa internasional dalam dimensi emosi yang dipengaruhi oleh ekologi sosial dan budaya.

Pertama, teori (geografi) emosi telah banyak digunakan sebagai landasan berpikir dalam memaknai diskursus emosi partisipan dalam berbagai konteks penelitian. Tuan (1977) memaknai emosi sebagai perasaan yang terbentuk dari pengalaman yang berulang dari hari ke hari. Emosi adalah bagian penting dalam komunikasi untuk mengungkapkan perasaan seseorang yang diwarnai oleh identitas dan tempat ketika dia berinteraksi secara sosial (Marvell \& Simm, 2018). Sementara itu, geografi emosi merupakan sebuah pendekatan untuk mengungkapkan emosi diri yang dikaitkan dengan jarak/ruang dalam interaksi sosial (Castro, Brady, \& Cook, 2020; Hargreaves, 2001). Secara eksplisit, Holton (2017) menunjukkan bahwa geografi emosi dapat diidentifikasikan melalui "komunikasi, perilaku, dan aktivitas" (hlm. 11). Dilandasi oleh teori dan konsep tersebut, memaknai perjalanan mahasiswa internasional dalam menghadapi situasi sebelum dan semasa pandemi dari 
sudut pandang geografi emosi dapat memberikan warna baru dalam memahami perasaan mereka.

Kedua, konsep kesejahteraan psikologis juga menjadi landasan penting dalam mempertimbangkan eksplorasi pengalaman mahasiswa internasional selama pandemi COVID-19. Ryff (1989, 1995) membuat model multidimensional tentang kesejahteraan psikologis individu yang terdiri dari enam dimensi, yaitu (1) otonomi, (2) pengenalan lingkungan, (3) perkembangan kepribadian, (4) hubungan yang positif dengan orang lain, (5) tujuan hidup dan (6) penerimaan diri. Setiap individu mengalami dimensi yang bervariasi karena adanya perbedaan karakteristik kepribadian. Dalam konteks individu yang memutuskan untuk melanjutkan studi ke negara asing, mahasiswa internasional harus memiliki persiapan yang matang dalam menghadapi berbagai tantangan psikologis, misalnya tekanan budaya, kerinduan pada kampung halaman, keterbatasan keterampilan sosial dan minimnya dukungan dari orang-orang di sekitarnya.

Penelitian tentang kesejahteraan psikologis telah banyak dilakukan oleh para akademisi, misalnya yang terkait dengan adaptasi psikologis, kepuasaan hidup dan harga diri pada mahasiswa internasional (Shafaei, Nejati \& Razak, 2018); lama tinggal di negara tempat studi, kemampuan berbahasa Inggris, sikap untuk meminta bantuan, depresi dan akulturasi (Li, Wang \& Xiao, 2014). Di masa pandemi ini, mahasiswa internasional mengalami beragam tantangan yang kompleks karena adanya kebijakan baru dari pemerintah setempat yang memengaruhi sistem pembelajaran, kehidupan sosial dan pekerjaan. Dengan demikian, sudut pandang psikologis berkontribusi dalam memaknai pengalaman mahasiswa internasional dalam menghadapi situasi baru, baik sebelum maupun semasa pandemi.

Selanjutnya, perspektif sosial budaya telah lama digunakan untuk mendokumentasikan pengalaman partisipan penelitian yang berhubungan dengan kehidupan bermasyarakat. Secara konseptual, Rakhimova, Yashina, Mukhamadiarova dan Sharipova (2016) menegaskan pentingnya keterampilan berkomunikasi antarbudaya yang memungkinkan pemelajar memahami kehidupan sosial budaya, baik kehidupan sosial budaya dirinya maupun orang lain. Sementara itu, Ma (2017) secara lebih konkret membuat kerangka teori sosial budaya yang mengintegrasikan tiga komponen terkait dalam diskursus interaksi sosial, antara lain aspek pribadi (misalnya, motivasi, keyakinan, pengetahuan), aspek eksternal (misalnya, guru, teman, keluarga) dan mediasi teknologi (misalnya, laman internet dan berbagai aplikasi teknologi). Dalam konteks mahasiswa internasional, Yu dan Wright (2016) menyimpulkan bahwa kerangka teori sosial budaya berperan penting dalam mengungkapkan bagaimana mahasiswa menghadapi tantangan norma sosial budaya di negara tujuan belajar. Pendekatan sosial budaya ini juga mencakup perilaku mahasiswa internasional selaku konsumen dalam membuat keputusan untuk memilih universitas tujuan belajar di luar negeri (McColl-Kennedy \& Fetter, 1999). Dengan pertimbangan tersebut, kerangka teori sosial budaya memiliki kontribusi penting dalam mengeksplorasi pengalaman mahasiswa 
internasional yang akan memilih tujuan studi ataupun sedang berjuang menuntaskan studinya baik sebelum maupun selama pandemi COVID-19.

Terakhir, dari perspektif linguistik fungsional, pengalaman mahasiswa internasional tidak terlepas dari representasi dan makna wacana atau diskursus sosial. Isu pengalaman mahasiswa internasional merupakan sebuah fenomena sosial yang bersifat dinamis karena beragam konteks sosial budaya membentuk pengalaman mahasiswa internasional. Untuk itu, linguistik fungsional sistemik sebagai teori sosial dapat digunakan sebagai kerangka teori untuk mengkaji beragam pengalaman mahasiswa internasional, termasuk pengalaman emosional mahasiswa internasional. Dalam hal ini, language appraisal yang diprakarsai oleh Martin dan White (2005) dapat digunakan sebagai kerangka teoretis/konseptual untuk mengkaji dimensi emosi mahasiswa internasional ketika berkuliah di luar negeri atau studi di negara orang lain. Dengan kata lain, teori language appraisal ini bisa memberi kontribusi dalam pengayaan analisis kritis mengenai isu-isu emosional dan sosial dalam konteks kajian mahasiswa internasional.

\section{RINGKASAN HASIL RISET MAHASISWA INTERNASIONAL DAN COVID-19}

Edisi khusus Journal of International Students berbahasa Indonesia ini menyajikan beragam temuan penelitian mengenai pengalaman dan tantangan baru yang dihadapi oleh mahasiswa internasional, terutama dalam situasi pandemi COVID-19. Dalam kondisi yang normal, mahasiswa internasional harus beradaptasi dengan berbagai hal di negara tempat tujuan studi. Kondisi pandemi ini menambah kompleksitas masalah dan menjadi tantangan tersendiri bagi mahasiwa internasional untuk dapat memenuhi harapan dan target akademiknya yang sesuai dengan rencana awal. Edisi khusus ini terdiri dari dua belas artikel yang ditulis oleh para akademisi dan peneliti dari berbagai perguruan tinggi di Indonesia dan Taiwan. Adapun beberapa negara yang merupakan tujuan studi mahasiswa internasional mencakup Australia, Belanda, Indonesia, Hongkong, Saudi Arabia, Selandia Baru dan Taiwan.

Para penulis dalam edisi khusus ini melaporkan temuan penelitian yang menggunakan pendekatan kualitatif dengan rancangan penelitian, antara lain studi kasus fenomenologi, studi naratif, studi wawancara dan kajian/tinjauan sistematik. Tiga artikel pertama dalam edisi khusus jurnal ini menekankan pengkajian isu yang berhubungan dengan penggunaan sumber informasi bagi mahasiswa internasional dalam memilih negara tujuan belajar, tantangan yang dihadapi oleh mahasiswa internasional yang belajar di Indonesia dan kesejahteraan psikologis mahasiswa internasional di luar negeri sebelum pandemi COVID-19. Meskipun konteks penelitian tersebut terjadi sebelum pandemi, ketiga artikel tersebut masih relevan dan memberikan implikasi praktis terhadap pengalaman akademik dan nonakademik mahasiswa internasional di masa pandemi COVID-19. Sementara itu, artikel lainnya mengkaji tentang pengalaman belajar dan perjuangan mahasiswa internasional 
dalam beradaptasi baik dengan kondisi akademik maupun dengan kondisi nonakademik serta tantangannya di masa pandemi COVID-19.

Artikel pertama, Pilihan Studi Luar Negeri dan Wisata: Penggunaan Sumber Informasi oleh Mahasiswa Pascasarjana Indonesia untuk Memilih Universitas di Luar Negeri, oleh Andriani Kusumawati melaporkan sumber informasi yang digunakan oleh mahasiswa pascasarjana Indonesia dalam memilih universitas untuk studi dan destinasi wisata. Temuan penelitian menunjukkan bahwa jejaring sosial yang disediakan secara daring oleh universitas membantu menyediakan informasi yang relevan bagi kebutuhan mahasiswa internasional. Temuan ini merekomendasikan pentingnya merancang strategi komunikasi pemasaran yang bermanfaat bagi perguruan tinggi untuk merekrut mahasiswa internasional sebelum mengambil keputusan.

Selanjutnya, artikel kajian sistematik yang berjudul Pengalaman Mahasiswa Internasional ketika Studi di Universitas di Indonesia oleh Restuning Widiasih, Yanti Hermayanti dan Ermiati memberikan gambaran komprehensif tentang pengalaman mahasiswa internasional ketika belajar di Indonesia. Hasil analisis menemukan tiga informasi utama, yaitu perbedaan sistem pendidikan, sosial budaya dan tantangan belajar dikarenakan masalah bahasa. Satu temuan spesifik lainnya yaitu perbedaan sistem pelayanan kesehatan. Kajian ini penting untuk mempersiapkan mahasiswa internasional secara akademik dan nonakademik sebelum belajar di Indonesia.

Dari sudut pandang kesejahteraan psikologis, Ferry Fadzlul Rahman, Hamka dan Kuan-Han Lin (Kesejahteraan Psikologis Mahasiswa Baru Indonesia di Taiwan) melaporkan kesejahteraan psikologis mahasiswa baru dari Indonesia yang berkuliah di Taiwan yang dilihat dari dimensi sosial, pendidikan dan budaya. Temuan utama menunjukkan bahwa mahasiswa baru asal Indonesia harus bernegosiasi dengan adaptasi budaya dan bersikap profesional dan disiplin dalam menjalani perkuliahan di Taiwan. Persiapan dan dukungan sosial diperlukan untuk mengurangi kemungkinan masalah kesejahteraan psikologis yang dihadapi oleh mahasiswa Indonesia yang baru belajar di Taiwan, misalnya menghindari stres.

Dalam artikel berikutnya yang berjudul Pengalaman Mahasiswa Thailand dalam Pembelajaran Daring di Universitas di Indonesia pada Masa Pandemi COVID-19 oleh Sandi Ferdiansyah, Supiastutik dan Ria Angin mengeksplorasi pengalaman belajar delapan orang mahasiswa Thailand di tiga universitas di Indonesia selama masa Pandemi COVID-19 dengan kerangka teori Ma (2017). Penelitian wawancara ini mengungkapkan bahwa kebijakan perguruan tinggi untuk menerapkan pembelajaran daring secara penuh merupakan hal yang baru bagi mahasiswa Thailand. Penelitian ini memberikan kontribusi teoretis dan empiris terhadap mahasiswa internasional yang melaksanakan pembelajaran daring selama pandemi COVID-19.

Lara Fridani, Ulfa Elfiah, Selfi Handayani dan Aschawir Ali, dalam studi naratif, Berpikir, Bersikap dan Bertindak: Perjuangan Seorang Ibu Berstatus Mahasiswa Internasional Program Doktor saat Pandemi COVID-19 di 
Australia, mengkaji cara berpikir, bersikap dan bertindak seorang mahasiswa internasional program doktor berstatus ibu dalam menghadapi tantangan saat pandemi COVID-19 di Australia. Hasil penelitian menunjukkan bahwa partisipan mengalami kendala dalam mengelola waktu dan kegiatan akademik, tantangan untuk berfokus pada studi, kekhawatiran terhadap keluarga di negara asal dan masalah finansial. Penelitian ini bermanfaat bagi para mahasiswa internasional dalam mempersiapkan dirinya dari segi akademik, fisik, psikologis, spiritual dan finansial.

Dari perspektif geografi emosi, dalam artikel yang berjudul Eksplorasi Emosi Mahasiswa Internasional Lajang di Hongkong dalam Menghadapi Pandemi COVID-19, Suprihatin (Kehok), Lilik Istiqomah, Rini Intansari Meilani dan Khoiriyah mengeksplorasi pengalaman emosi mahasiswa internasional yang berstatus lajang yang sedang menyelesaikan program doktoral di Hongkong selama masa pandemi COVID-19. Dengan menggunakan teori emosi yang dikemukakan oleh Hargreaves (2001) sebagai alat analisis, penelitian ini menemukan bahwa situasi pandemi tersebut memengaruhi kondisi emosi para mahasiswi dalam lima hal, yaitu (1) proses penyelesaian studi, (2) kestabilan kondisi psikologis, (3) komunikasi dengan keluarga, (4) masalah keuangan dan (5) kestabilan spiritual.

Artikel yang berjudul Pengalaman Emosional Mahasiswa Program Doktor Asal Indonesia Belajar di Australia selama Pandemi COVID-19 oleh Supiani, Dina Rafidiyah, Yansyah dan Hafizhatu Nadia melaporkan studi naratif yang mendokumentasikan pengalaman emosional dua mahasiswa Indonesia yang sedang menempuh program doktor di Australia selama masa pandemi COVID-19. Temuan penelitian menunjukkan bahwa pengalaman emosional kedua partisipan dipengaruhi oleh sikap dan kepribadian mereka. Hasil riset ini menyarankan bahwa untuk mengurangi perasaan cemas dan stres selama masa pandemi COVID-19, membangun kemandirian partisipan, dukungan keluarga, dukungan sosial dan dukungan universitas sangat diperlukan.

Sementara itu, dari perspektif geografi emosi yang sama, dalam artikel yang berjudul Pengalaman Geografi Emosi Mahasiswa Indonesia yang Menempuh Program Doktor di Selandia Baru selama Masa Pandemi COVID19, Johanes Leonardi Taloko, Martin Surya Putra dan Yenny Hartanto menggali pengalaman emosi mahasiswi internasional yang berasal dari Indonesia saat pandemi COVID-19 di Selandia Baru. Berlandaskan teori geografi emosi, penelitian ini mengungkapkan bahwa secara geografi fisik, partisipan menjadi akrab dengan kelompok yang tinggal dalam satu lingkungan. Penelitian ini berimplikasi bahwa mahasiswa internasional perlu memperoleh dukungan sistem sosial yang baik dan memiliki kecerdasan emosi untuk memelihara kesehatan mental mereka.

Dewi Puspitasari, Wiwien Widyawati Rahayu, Rahmatunnazilah dan Suwarno dalam studi yang mereka lakukan (Mengeksplorasi Perasaan Mahasiswa Internasional: Saat Kita Belajar secara Virtual selama Pandemi COVID-19) melaporkan emosi dua mahasiswa Indonesia yang sedang belajar 
di Arab Saudi dan Belanda selama masa pandemi COVID-19. Temuan utama menunjukkan adanya kekhasan dalam strategi pengambilan keputusan dan penanggulangan masalah berdasarkan indikator sikap profesional, dukungan keluarga dan kemampuan berdamai pada diri sendiri. Hasil riset menyarankan bahwa modal kultural yang terstrukturasi dapat digunakan sebagai landasan untuk mengatasi masalah emosional.

Studi terkait pembelajaran bahasa Indonesia bagi Penutur Asing (BIPA), Geografi Emosi Mahasiswa Internasional dalam Belajar Bahasa Indonesia secara Daring pada Masa COVID-19 oleh Gatut Susanto, Suparmi dan Endah Yulia Rahayu mengeksplorasi geografi emosi mahasiswa internasional yang belajar BIPA secara daring pada masa COVID-19. Temuan penelitian menunjukkan bahwa pembelajaran BIPA yang dilaksanakan secara daring pada masa COVID-19 memengaruhi geografi emosi mahasiswa internasional. Hasil penelitian ini menyarankan kepada mahasiswa internasional untuk berusaha memiliki perasaan positif dan menjaga perasaan tersebut supaya berhasil dalam belajar bahasa Indonesia secara daring selama masa COVID19.

Cerita mahasiswa internasional yang belajar bahasa Indonesia juga dilaporkan oleh Hastowohadi, Rina Wahyu Setyaningrum dan Fida Pangesti dalam artikel yang berjudul Pembelajaran Jarak Jauh Darurat COVID-19. Penelitian ini mengeksplorasi pengalaman mahasiswa internasional pada kelas BIPA dalam pembelajaran jarak jauh darurat di masa pandemik COVID-19. Penelitian ini menemukan bahwa perubahan moda pembelajaran menyebabkan mahasiswa kehilangan banyak kesempatan dan tidak dapat memenuhi harapannya di awal. Kontribusi penelitian ini menekankan pengelolaan program yang efektif untuk meminimalisasikan munculnya emosi negative dalam diri mahasiswa internasional.

Artikel pendek yang berjudul Persepsi Mahasiswa Internasional terhadap Program Kuliah Kerja Nyata Virtual (KKN-V) di masa Pandemi COVID-19 oleh Sitti Nurfaidah, Anna Riana Suryanti Tambunan, Fadhila Yonata, Dewi Kurniawati dan Reni Puspitasari Dwi Lestariyana menyajikan hasil empiris mengenai pengalaman dua mahasiswa internasional dari Thailand yang melaksanakan program kuliah kerja nyata virtual $(\mathrm{KKN}-\mathrm{V})$ di Indonesia. Temuan studi ini mengungkapkan bahwa mahasiswa menunjukkan emosi positif (misalnya, sikap kreatif dan kontributif) dan emosi negative (misalnya, keluhan terhadap kendala teknis dan nonteknis). Hasil studi ini menyarankan pentingnya bantuan dan kerjasama antara dosen pembimbing lapangan (DPL) dan anggota kelompok, sehingga berbagai kegiatan dalam program $\mathrm{KKN}-\mathrm{V}$ berhasil terlaksana.

\section{PENUTUP}

Edisi khusus berbahasa Indonesia yang bertemakan International Students and COVID-19 [mahasiswa internasional dan COVID-19] mengkaji isu pengalaman mahasiswa internasional dari beragam landasan teoretis dan 
konseptual, antara lain geografi emosi, kesejahteraan psikologis, pendekatan sosial budaya, dan linguistik fungsional sistemik. Edisi ini memberikan empat implikasi praktis. Pertama, calon mahasiswa, yang akan melanjutkan studi di luar negeri selama masa pandemi COVID-19, perlu mencari informasi tentang perguruan tinggi luar negeri. Calon mahasiswa internasional juga perlu beradaptasi dengan kemungkinan perubahan sistem pembelajaran jarak jauh yang diterapkan oleh institusi pendidikan tinggi. Selain itu, mereka juga perlu menyiapkan kondisi fisik dan psikologis untuk penerapan kebijakan karantina di negara tujuan belajar. Kedua, mahasiswa dengan status lajang maupun yang membawa serta keluarganya yang sedang menempuh studi di luar negeri perlu membangun motivasi dan kemandirian belajar serta menyiapkan diri secara akademik, fisik, psikologis, finansial dan spiritual. Ketiga, faktor teman, keluarga dan pembimbing akademik merupakan bentuk dukungan sosial bagi mahasiswa internasional untuk menyelesaikan studi di tengah situasi krisis. Implikasi keempat adalah institusi perguruan tinggi perlu membuat kebijakan yang tepat, termasuk kebijakan pengelolaan program perkuliahan yang kondusif secara akademik dan psikologi di masa pandami dan pascapandemi.

\section{Pernyataan Editor [Disclosure Statement]}

Editor menyatakan bahwa tidak ada konflik kepentingan dalam hal riset, kepengarangan dan publikasi artikel ini. [The editors declared no potential conflicts of interest with respect to the research, authorship and publication of this article].

\section{Pernyataan Kontribusi Editor [Editors' Contribution Statements]}

Handoyo Puji Widodo: Mengonsep ide (awal), mempertajam draf akhir, mengkaji dan mengedit (setara), dan menambahkan referensi [conceptualization of ideas, strengthening a final draft, reviewing and editing (equal), and additional resources]; Sandi Ferdiansyah: Mengonsep ide (penguat), menulis draf awal editorial (penguat), mengevaluasi (setara), mengedit (setara), memformat (penguat) [conceptualization of ideas (supporting), writing-original draft of editorial (supporting), reviewing (equal), editing (equal), and formatting (supporting)]; Lara Fridani: menulis draf awal editorial (penguat), mengevaluasi (setara), mengedit (setara) [writing-original draft of editorial (supporting), reviewing (equal) and editing (equal)].

\section{DAFTAR REFERENSI}

Azorin, C. (2020). Beyond COVID-19 supernova: Is another education coming? Journal of Professional Capital and Community. Terbit pertama online (hlm. 1-10). DOI: 10.1108/JPCC-05-2020-0019

Baloran, E. T. (2020). Knowledge, attitudes, anxiety, and coping strategies of students during COVID-19 pandemic. Journal of Loss and Trauma. Terbit pertama online (hlm. 1-8). DOI: 10.1080/15325024.2020.1769300

Bayham, J., \& Fenichel, E. P. (2020). Impact of school closures for COVID-19 on the US health-care workforce and net mortality: A modelling study. The Lancet Public Health, 5(5), 271-278. DOI: 10.1016/S24682667(20)30082-7 
Blankenberger, B., \& Williams, A. M. (2020). COVID and the impact on higher education: The essential role of integrity and accountability, Administrative Theory \& Praxis. Terbit pertama online (hlm. 1-20). DOI: $10.1080 / 10841806.2020 .1771907$

Castro, L. R., Brady, M., \& Cook, M. (2020). Negotiating 'ideal worker' and intensive mothering ideologies: Australian mothers' emotional geographies during their commutes. Social and Cultural Geography. Terbit pertama online, (hlm. 1-19). DOI: 10.1080/14649365.2020.1757140

Cleland, J., McKimm,J., Fuller, R., Taylor, D., Janczukowicz, J., \& Gibbs, T. (2020). Adapting to the impact of COVID-19: Sharing stories, sharing practice, Medical Teacher. Terbit pertama online (hlm. 772-775). DOI: 10.1080/0142159X.2020.1757635

Hargreaves, A. (2001). Emotional geographies of teaching. Teachers College Record, 103(6), 1056-1080. DOI: 10.1111/0161-4681.00142

Haverila, M. J., Haverila, K., \& McLaughlin, C. (2020). Variables affecting the retention intentions of students in higher education institutions: A comparison between international and domestic students. Journal of International Students, 10(2), 358-382. DOI: 10.32674/jis.v10i2.1849

Holton, M. (2017). A place for sharing: The emotional geographies of peersharing in UK University halls of residences. Emotion, Space and Society, 22, 4-12. DOI: 10.1016/j.emospa.2016.11.003

Li, J., Wang, Y., \& Xiao, F. (2014). East Asian International Students and Psychological Well-Being: A Systematic Review. Journal of International Students, 4 (4) 301-313.

Ma, Q. (2017). A multi-case study of university students' language-learning experience mediated by mobile technologies: A socio-cultural perspective. Computer Assisted Language Learning. Terbit pertama online (hlm. 1-21). DOI: 10.1080/09588221.2017.1301957

Martin, J., \& White, P. (2005). The language of evaluation: Appraisal in English. New York: Palgrave Macmillan.

Marvell, A., \& Simm, D. (2018). Emotional geographies experienced during international fieldwork: An evaluation of teaching and learning strategies for reflective assessment. Journal of Geography in Education. Terbit pertama online, (hlm. 1-16). DOI: 10.1080/03098265.2018.1460806

McColl-Kennedy, J. R., \& Fetter Jr., R. E. (1999). Dimensions of consumer search behavior in services. Journal of Services Marketing, 13(3), 242-265. DOI: $10.1108 / 08876049910273871$

Murphy, M. P. A. (2020). COVID-19 and emergency e-learning: Consequences of the securitization of higher education for post-pandemic pedagogy, Contemporary Security Policy. Terbit pertama online (hlm. 492-505). DOI: 10.1080/13523260.2020.1761749

Raaper, R., \& Brown, C. (2020). The Covid-19 pandemic and the dissolution of the university campus: Implications for student support practice. Journal of Professional Capital and Community. Terbit pertama online (hlm. 1-7). DOI: 10.1108/JPCC-06-2020-0032

Rakhimova, A. E., Yashina, M. E., Mukhamadiarova, A. F., \& Sharipova, A. V. (2016). The development of sociocultural competence with the help of 
computer technology. Interchange. Terbit pertama online, (hlm. 1-16). DOI: $10.1007 / \mathrm{s} 10780-016-9279-5$

Ryff, C. D. (1989). Happiness is everything, or is it? Explorations on the meaning of psychological well-being. Journal of Personality and Social Psychology, 57, 1069-1081. DOI:10.1037/0022-3514.57.6.1069

Ryff, C. D. (1995). Psychological well-being in adult life. Current Directions in Psychological Science 4, 99-104. DOI: 10.1111\%2F14678721.ep10772395

Shafaei, A., Nejati, M., \& Razak, N. A. (2018). A model of psychological wellbeing among international students. Educational Psychology, 38(1), 1737, DOI: $10.1080 / 01443410.2017 .1356447$

The Guardian. (11 April 2020). Universities brace for huge losses as foreign students drop out. Diakses tanggal 8 Oktober 2020 dari https://www.theguardian.com/education/

Tran, L. T. (2020). Teaching and engaging international students: People-topeople connections and people-to-people empathy. Journal of International Students, 10(3). xii-xvii. DOI:10.32674/JIS.V10I3.2005

Tuan, Y. F. (1977). Space and place: The perspective of experience. Minneapolis, MN: University of Minnesota Press.

UNESCO. (2019). Higher education. Diakses tanggal 18 Agustus 2020 dari http://data.uis.unesco.org/Index.aspx?queryid=172

Urban, E., Orbe, M. P., Tavares, N. A., \& Alvarez, W. (2010). Exploration of Dominican international students' experiences. Journal of Student Affairs Research and Practice, 47(2), 233-250.

Yu, B., \& Wright, E. (2016). Socio-cultural adaptation, academic adaptation and satisfaction of international higher degree research students in Australia. Tertiary Education and Management, 22(1), 49-64. DOI: 10.1080/13583883.2015.1127405

\section{BIOGRAFI SINGKAT EDITOR [NOTES ON EDITORS]}

Handoyo Puji Widodo saat ini bekerja sebagai Profesor Riset di King Abdulaziz University yang berkedudukan di Jeddah, Saudi Arabia. Widodo sudah menyunting beberapa buku dengan penerbit bereputasi dunia (Springer, Routledge, Multilingual Matters) dan edisi khusus/tematik jurnal internasional terindeks Scopus (The Indonesian Journal of Applied Linguistics, Sexuality and Culture).

Handoyo Puji Widodo is a Research Professor at King Abdulaziz University based in Jeddah, Saudi Arabia. Widodo has edited several books with reputable international publishers (Springer, Routledge, Multilingual Matters) and special issues of Scopus-indexed journals (The Indonesian Journal of Applied Linguistics, Sexuality and Culture).

Sandi Ferdiansyah bekerja sebagai dosen pada Program Studi Pendidikan Bahasa Inggris di Institut Agama Islam Negeri (IAIN) Jember, Indonesia. Minat akademik penulis meliputi metodologi pengajaran bahasa Inggris, penggunaan teknologi 
untuk peningkatan pembelajaran bahasa dan pengembangan profesi guru. Email: sanjazzyn@yahoo.com.

Sandi Ferdiansyah is a lecturer in the Department of English Education of Institut Agama Islam Negeri (IAIN) Jember, Indonesia. His research interests include methodology in TESOL, technology-enhanced language learning, and teacher professional development.Email:sanjazzyn@yahoo.com.

Lara Fridani adalah tenaga pengajar di Program Studi Pendidikan Anak Usia Dini di Fakultas Ilmu Pendidikan Universitas Negeri Jakarta. Fokus penelitian penulis di bidang psikologi pendidikan dan perkembangan, keluarga dan asesmen. Email:1fridani@unj.ac.id

Lara Fridani is a lecturer in the Department of Early Childhood Education at the Faculty of Education of Universitas Negeri Jakarta. Her research focuses on educational and developmental psychology, family and assessment. Email: lfridani@unj.ac.id 